\title{
Partible penitents: a response to comments
}

Ma R K Mosкo Australian National University

I thank the respondents for their remarks and for the opportunity to clarify and elaborate upon several pivotal points in my article. Relevant concerns include: my chief focus - the core ritual practices of indigenous Melanesian religions and Christianity - as distinct from the respondents' interests in 'larger realities'; the formal correspondences and differences between pre- and post-conversion ritual performances; conceptual clarifications of dividuality, relationalism, Christianity's supposed distinctive individualism, and possessive individualism; adaptations of NME models of personhood to situations of change; the suitability of my ethnographic, analytical, and comparative methods; what constitutes 'change', 'continuity', and 'non-change'; and the adequacy of my attempt at bridging Melanesian anthropology's current impasse.

As Barker, Knauft, Errington and Gewertz, and Robbins variously stress, the topic of religious change in Melanesia covers a vast field of well-researched themes as to how Melanesian cultures have undergone 'ruptures', 'breaks', or 'disjunctures' resulting from diverse and protracted encounters with colonialism and modernity. But the tangled, multi-faceted, and perhaps livelier changes which have involved Melanesian Christianity at that scale, while hardly irrelevant to my analysis, are not my chief focus, which their critiques barely address. My article concentrates on the precise character of the transition of modes of personhood and agency in contexts of conversion between indigenous religions and varieties of Christian ritual practice (except, in the case of Karavar, between earlier and later Christian ritual forms). I presume that this 'severely constricted conception of Melanesian Christianity', as Barker (p. 248) construes it, is crucial to the Melanesians who have internalized it as well as to those indigenous scholars Knauft mentions, regardless of the complex historical processes which might have preceded or accompanied it. I surmise, in other words, that Melanesian Christians' culturally variable views of the character of their religious identities and ritual interactions - that is, their personal reciprocities of grace, blessings, sins, praises, prayers, and so on, with one another and with God, Jesus, Holy Spirit, the Devil, and other spiritual agencies - are conceived as set apart, as holy or sacred. This surely has much to do with people's 
experience of the 'larger realities of Christianity' and thereby merits dedicated anthropological attention.

Robbins has elsewhere observed that despite the 'widely acknowledged importance' of ritual in Pentecostal-charismatic Christianity, its detailed study 'is notably scarce in the literature' (2004b: 126). He has even conceded the presence of formal similarities and analogous core features between the 'Spirit-filled rituals' of some varieties of Christianity and 'the kind of religions anthropologists have long studied in the region' (2001: 8; see also 2004a: 32; 2004b: 126, 129; Knauft 2001: 636). Yet his and the other respondents' original works and commentaries on my article fail to attribute much, if any, significance, to those issues. In close conformity with widely held views, they presuppose instead that Melanesian religious change evinces radical discontinuities between 'relationalist' and 'individualist' orientations and actions, which they validate through token references, respectively, to seminal works of the NME (e.g. M. Strathern, Wagner) and authoritative testaments (e.g. Dumont, Burridge) as to Christianity's inherent individualism. While I do not dispute that diverse aspects of modernity including Christianity have conditioned profound changes across the region, the empirical evidence I draw from their ethnographies and my own leads to a different conclusion: that the specific modes of personhood and agency of indigenous Melanesian religions and introduced Christianity are, in contexts of ritual performance, isomorphic, conforming closely with theoretical formulations of giftexchange and personal partibility. I view such similarities as significant and as serving exceedingly well the 'purposes of illustrating the limits of common Occidental assumptions about personhood and exchange' which Knauft (p. 244) recommends. Moreover, I argue that those formal compatibilities and the cultural dynamics underlying them may well have played critical roles in shaping the manner in which other social transformations have unfolded - precisely those changes beyond my principal focus that others have documented. I do not enumerate the sorts of "non-NME exchanges out there in which bounded persons exchange objects that are not parts of themselves', which concern Robbins (p. 241) and others, simply because, in the comparative survey of ritual contexts that I examine, there appears to be little evidence for them.

While Barker, for example, argues that partible personhood 'tells us nothing specific about Christianity' (p. 249), I take Melanesian co-religionists' experiences of religious interactions with their deities and one another and their understandings about the detachable elements of themselves as persons to be non-arbitrary aspects of the two bodies of religious tradition and non-trivial dimensions of their comparability. Similarly, while Errington and Gewertz acknowledge that the 'language of partibility' is familiar to virtually all Christians, they refrain from taking serious account of the implications of that observation. In their original works which I considered, the respondents adjudged different modes of personhood to be so consequential that they chose such terms as 'relationalist' and 'individualist' to gloss the overall character of conversions and broader transformations - glosses which, in their commentaries, none of them now defend. If the 'individualism' that is supposedly specific to Christianity in its defining ritual contexts can be demonstrated to consist instead in processes of dividuality and elicitation, this might reveal something important about Christianity in general. I would make analogous claims as regards my critique of indigenous 'relationalism'. It is noteworthy that none of the respondents who previously cited Dumont and/or Burridge have commented upon, much less challenged, 
my demonstration of the formal compatibility of Christianity's supposedly unique 'individualism' and the dividuality of the NME's partible person; nor have they disputed the relevance of the subject/object distinction to that analysis. With few exceptions (see below), none of the respondents have offered substantive data which might cast doubt on my interpretations of indigenous and Christian ritual practices as instances of dividuality and elicitation.

Respondents' criticisms of my article often target methodological concerns, but take insufficient account of the different scales of our respective perspectives. Knauft, for instance, objects to my partial treatments of others' fuller ethnographic materials as 'selective quotation' (p. 245) - a claim I readily accept, but which follows some of the best anthropological precedents of empirical analysis and theoretical synthesis. In the forty pages and over 200 accompanying endnote entries of chapter 2 of The gift, where he sought to illustrate ethnographically his model of 'total social facts', for example, Mauss (1967) selectively extracted elements from Malinowski's and Boas's much more complex accounts of Trobriand kula and Northwest Coast potlatch exchange, and then he proceeded to reassemble them in accord with purposes that diverged from their original pragmatic and particularist frameworks. This was not simply 'leaving ethnography behind' or 'mangling' it, even though in numerous particulars it produced results at odds with what Malinowski and Boas thought they had found in the field (see comments below on 'explanation'). By such 'straitjacketing', Mauss was able to re-contextualize the ethnographic facts as originally presented so as to shed new light upon each case and to establish formal commonalities between them, despite their lack of known historical connections. Similarly, my treatments of the indigenous religions and Christian practices of Maisin, Gebusi, Karavar, and Urapmin selectively cite passages of the ethnographers' original works and rearrange them to epitomize and illuminate the character of unfolding religious changes and the transformative patterns that they appear to share with one another, with North Mekeo, and, by implication, with Christianity in the West.

This follows well-established anthropological procedures of constructing synthetic models ('analytic fictions') (Strathern 1988) to interpret the phenomena we observe. Although they happen to possess particularly distinguished NME credentials (e.g. Foster 1995: 227-48; Gregory 1982; Strathern 1988, as well as Mauss), these methods are not limited to that orientation. Sahlins's (1992) formulation of the 'develop-man' concept which Robbins and Errington and Gewertz recommend (see below) consists similarly in selecting and reassembling Mendi, Kwakiutl, Hawai'ian, and Fijian materials towards ends that deviate from the original accounts, suggesting that this 'old-fashioned' method, as Barker, Knauft, and Robbins view it, may prove relevant for the study of change even in the post-paradigm era. For that matter, Robbins's (2004a) model of 'adoption', an adaptation of Sahlins's conceptualization of reproduction and transformation, and his (2005: 5-10) 'back door' reformulation of Sahlins's theories of develop-man, development, and structural change (see below) effectively highlight 'humiliation' and critiques of 'continuity' which he perceives as exceeding Sahlins's intents. Our anthropological genealogy reveals methodological continuities which are at least as pronounced as the theoretical ruptures. Moreover, the considerable analytical merits of the respondents' original ethnographies rely no less on selectively cited observations from field notes and other sources and creatively assembling them into coherent portraits of the phenomena they purport to describe and explain. 
The respondents' objections that I have distorted their materials also involve confusions over explanation, specifically between that which explains (explicans) and that which is to be explained (explicandum). Gebusi pronouncements that they are 'exchanging the past', Urapmin assertions that 'everything has changed', Karavarans' claims that they should concentrate resources 'on themselves and their immediate family', and so on, constitute important empirical data which are to be explained, but are such statements, by themselves, capable of explaining very much? My article simply ponders the relations between such statements and other data in the immediate contexts of their articulation, seeking answers to such questions as: What specifically is exchanged with the past, and with which elements of the past? Does 'getting to heaven themselves' necessarily mean something separate from peoples' observed attempts at reciprocally helping each other achieve that goal? How do actions on behalf of 'immediate family members' and 'one's own children' transparently express the commodity logics of development (see below) and bounded individual personhood rather than dividualist sociality? Do assertions of the Christian soul's immortality and indivisibility equate with the individuality' of the total person, or just a detachable part? To what specifically do Christian references to 'self' refer? The total self, or aspects of it? Are Christians' perceptions of rupture and conversion formally incommensurable with familiar Melanesian pre-Christian forms of personal detachment? Are such changes absolutely new or absolute?

My answers to these and other questions do not derive, as Robbins presumes, solely from my experience of North Mekeo blood de-conception but from careful analyses of the ethnography that he and the other respondents' texts provide. He illustrates my 'rough or inaccurate ethnographic reports' and my commitment to perceiving 'continuity' wherever he registers change, for example, by my ignoring his pronouncement that 'the Urapmin had "no indigenous tradition of" possession' (p. 242). In his original description, the 'new' practice of Holy Spirit possession (kisim Spirit) consisted of being violently " "kicked" by the Spirit', 'feelings of enormous sadness', extremely hot bodies, crying in anguish, and recognition of 'the enormity of their need for correction' (2004a: 131). My likening of those experiences to 'pre-Christian possession by nature and ancestral spirits' (my terms, p. 242) stems from Robbins's account, summarized in my article, of how spirits and 'devils' are thought to cause illness and of the procedures employed for prevention and cure. Both after Christian conversion and earlier, illness was understood to result from contagious contacts with spirits, the places they inhabit, or their material remains, or by entering into relations of reciprocal exchange with them (i.e. personal detachments and attachments). Preventive counter-measures analogous to a 'modern toxic waste cleanup effort' included steps to avoid contagious spiritual influences, and cures were effected through sacrifices intended to 'get rid of' and 'throw off offending spirits (2004a: 135, 148-9, 168, 180, 210). By my reckoning, the spirit-induced contagions of Urapmin illness qualify as 'possession' akin to kisim Spirit contaminations by God's Holy Spirit. Unsurprisingly, at the conclusion of the kisim Spirit possessions, participants were left 'feeling extremely spiritually healthy' (2004a: xix, emphasis added). Robbins's insistence on the pre-Christian absence of possession perhaps reveals more about his proclivity to recognize change at the expense of continuity, consistent with his 'adoption' and 'humiliation' models (see below), than any inaccuracies and/or lack of ethnographic specificity on my part. 
As regards other seeming ethnographic inaccuracies and distortions, I urge interested readers to cross-check my analyses with the texts and citations I have organized in support of them.

In arguing that Melanesian or other Christians, in their ritual performances, are acting in accord with NME construals of dividuality, I have nowhere claimed that the same persons cannot in other contexts interact with others in ways compatible with the tenets of possessive individualism. The relations of New Church Karavarans with non-members, as highlighted by Errington and Gewertz, are a possible case in point. However, I would still hesitate to jump immediately to that or any other conclusion without further scrutiny. There is plenty of room in the Christianities I am familiar with, whether Protestant or Catholic, to imagine circumstances where non-believers are denied God's blessings (detachments) as transmitted through believers until they have renounced (detached) tokens of the Devil previously attached to their own persons. That, and developed New Church members' sequestering of income from extended kin, might look like bounded, possessive individualism, but is it? Does the pre-Christian Melanesian's capacity to withhold gifts from certain relations automatically make him/her a possessive individual? As Dumont acknowledged and as I cite in my article, the transformation of personhood at issue here is 'so radical and so complex that it took at least seventeen centuries of Christian history to be completed, if indeed it is not still continuing in our times' (1985: 94, emphasis added). Moreover, I have argued in a series of studies (referenced in my article which the respondents have not addressed) that numerous dimensions of North Mekeo change and modernity which appear superficially as instances of individual agency (e.g. commodification, adoption of Western styles of clothing and architecture, syncretism, charismatic Catholicism, gender equality, etc.; see Mosko 1999; 2001; 2002; 2007; forthcoming) have been accommodated through processes of partibility and elicitation. The claims I make about the pivotal role of dividual personhood in relation to Christian ritual and religious change can therefore be extended to some of the region's 'larger realities', further bridging the bifurcation in Melanesian anthropology which has long been tolerantly ignored.

The difference between my own and Foster's (1995) earlier attempt at synthesis, which Barker mistakenly claims I traduce, is relevant here. The bridges we attempt to construct are simply different to each other. Foster's consists in conducting the two analyses - the historical and the ahistorical - side by side, in restricting the operation of dividual personhood mainly to indigenous transactions, and in focusing on domains of activity (bisnis and kastom) other than Christianity. The bridge I am seeking to build instead synthesizes the two frameworks through analyses which focus on points of intersection across seemingly distinct domains (in this instance, different religions) where notions of dividual agency and elicitation appear to be shared.

I suggest to my respondents that, because of my analytical constriction of Melanesian Christianity to transactions at its ritual core, I have discerned dimensions of Christian sociality that have been obscured in less focused perspectives on change, or indeed in perspectives which have taken as axiomatic that indigenous and Christian modes of personhood and agency are intrinsically distinct from one another. The mode of sociality I have identified as shared between indigenous Melanesian religions and introduced Christianities amends and greatly improves upon the entrenched essentializations of 'relationalism versus individualism' and 'Melanesia versus the Rest' which have for so long dogged the profession. 
The final gulf of misunderstanding between myself and the respondents, especially Robbins, concerns my supposed stress upon 'continuity' at the expense of change precisely where I have struggled to transcend the NME's conventional synchronic limitations. To construe my approach as emphasizing continuity over change entails a nonsensical distinction between those notions. In Robbins's commentary, for example, the 'continuity' which he perceives as 'banal' in my analysis he defines as change - that is, 'change as a process whereby people incorporate anything new they encounter into their old understandings, and thus reproduce their traditions even as they may open them to incremental transformations' (p. 242). I take this to mean that formally there are two sorts of 'change' at issue, not simply 'change' and 'nonchange', on the authority of Robbins (2001: 7-9; 2005) himself, where he has endorsed Sahlins's construals of develop-man versus development (1992) and structural reproduction versus transformation (1985). For Sahlins, 'change' qua develop-man and reproduction is the assimilation of exogenous elements into pre-existing relations and according to pre-existing values, but where the underlying 'traditional' category structures are left largely intact - a key qualification, incidentally, that Robbins (2005: 5-10) elides in his otherwise sensitive summary of Sahlins's theorizing of develop-man. With 'change' of the order of development and transformation, however, the pre-existing structure of category relations is compromised and reorganized. Critically, it is in the latter context where Sahlins has identified the emergence of individualistic modes of personal identity and agency. The cases of Melanesian Christianity which I have examined - where we witness considerable changes in cultural or religious content but where the structures of reciprocity and dividuality facilitating those changes have not yet been fundamentally ruptured - correspond closely to Sahlins's develop-man and/or reproduction models of incremental change. This is precisely the situation of change which Robbins outlines for the first-stage of Urapmin conversion to Christianity and their initial uses of introduced state currencies (2004a: 7, 87-8, 115, 122 passim). What then distinguishes the second-stage Urapmin 'adoption' of charismatic Christianity from their initial incorporations of Christianity and money? Answer: a bald presupposition of Pentecostal Christianity's distinctive 'hard' tendency 'to hold its shape as it travels' (Robbins 2001: 7-8), meaning 'non-change'. There might be legitimate room after all in anthropological thinking about social change for a 'science of continuity'.

Therefore, Maisin, Gebusi, Karavaranas, Urapmin, Mekeo, and, I suspect, other Melanesians can become Christians, and yet exhibit dividual modes of elicitation, interaction, and agency that are characteristic of both their indigenous and adopted religions. If we are to take Robbins's and Errington's and Gewertz's announced allegiance to Sahlins's models of change as a measure, we are entitled to ask: Have Melanesian Christians in the context of ritual yet embarked on the path of development and possessive individualism, or are they rather still engaged in develop-man-type relations and ritual transactions that are compatible with dividual personhood? Moveover, if humiliation has played the role of promoting change as argued by Robbins and Sahlins, if Christian sin is a form of ritual humiliation, and if humiliation and sin involve experiences of self, then the character of that 'self' must not be taken for granted. It seems reasonable to suppose that Melanesians' sense of sin as a specifically detachable part of their persons could be a crucial step along paths that might eventually lead to development as well as salvation. 
The NME and its central notions of personal partibility and elicitation, modified in the ways I have proposed, may therefore have important insights to offer the study of Melanesian social change, religious and otherwise.

\section{REFERENCES}

Dumont, L. 1985. A modified view of our origins: the Christian beginnings of modern individualism. In The category of the person: anthropology, philosophy, history (eds) M. Carrithers, S. Collins \& S. Lukes, 93-122. Cambridge: University Press.

Foster, R. 1995. Social reproduction and history in Melanesia: mortuary ritual, gift exchange and custom in the Tanga Islands. Cambridge: University Press.

Gregory, C. 1982. Gifts and commodities. London: Academic Press.

Knauft, B. 2001. Comment on B. Douglas's 'From invisible Christians to gothic theatre: the romance of the millennial in Melanesian anthropology'. Current Anthropology 42, 636-7.

Mauss, M. 1967. The gift. New York: Norton.

Моsко, M. 1999. Magical money: commoditization and the linkage of maketsi ('market') and kangakanga ('custom') in contemporary North Mekeo. In Money and modernity (eds) D. Akins \& J. Robbins, 41-61. Pittsburgh: University of Pittsburgh Press.

2001. Syncretic persons: agency and personhood in recent charismatic ritual practices among North Mekeo (PNG). In Beyond syncretism (eds) J. Gordon \& F. Magowan. The Anthropological Journal of Australia (special issue) 12, 259-76. 89-109.

2007. Fashion as fetish: body decoration, love magic, and Western clothing among North Mekeo (PNG). The Contemporary Pacific 19, 39-83.

forthcoming. Gifts that change: personal partibility, agency and Christianity in a changing Melanesian society. New York: Berghahn.

Robbins, J. 2001. Introduction: global religions, Pacific Island transformations. In Charismatic and Pentecostal Christianity in Oceania (eds) J. Robbins, P. Stewart \& A. Strathern. Journal of Ritual Studies (special issue) 15: 2, 7-12.

2004a. Becoming sinners: Christianity and moral torment in a Papua New Guinean society. Berkeley: University of California Press.

2004b. The globalization of Pentecostal and charismatic Christianity. Annual Review of Anthropology 33, $117-43$.

2005. Introduction - humiliation and transformation: Marshall Sahlins and the study of cultural change in Melanesia. In The making of global and local modernities in Melanesia: Humiliation, transformation and the nature of cultural change (eds) J. Robbins \& H. Wardlow, 3-22. Burlington, Vt: Ashgate.

SAHLins, M. 1985. Islands of history. Chicago: University Press. 1992. The economics of develop-man in the Pacific. Res 21, 13-25.

Strathern, M. 1988. The gender of the gift: problems with women and problems with society in Melanesia. Berkeley: University of California Press.

Mark Mosko is Professor of Anthropology, Australian National University. Publications include the forthcoming Gifts that change: personal partibility, agency and Christianity in a changing Melanesian society (Berghahn).

School of Culture, History and Language, College of Asia and the Pacific, Australian National University, Canberra ACT 020o, Australia.mark.mosko@anu.edu.au 